\title{
Ultrastructural evaluation of human keratinocyte growth and differentiation on a fibrin substrate $^{1}$
}

\author{
Avaliação ultraestrutural do crescimento e da diferenciação de queratinócitos sobre um substrato \\ de fibrina
}

\begin{abstract}
Daniela Yukie Sakai TanikawaI, Nivaldo Alonso ${ }^{\mathrm{II}}$, Marisa Roma Herson ${ }^{\mathrm{II}}$, Monica Beatriz Mathor ${ }^{\mathrm{III}}$, Elia Garcia Caldini ${ }^{\mathrm{IV}}$,

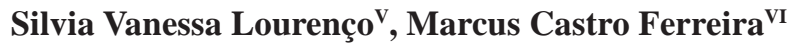

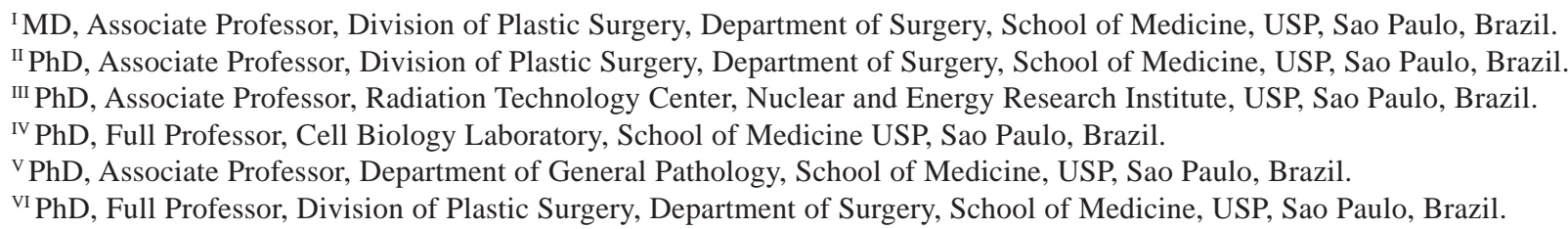

\begin{abstract}
Purpose: In order to circumvent several difficulties that have been met in the routine use of the in vitro keratinocyte cultures using the standard procedure described by Rheinwald and Green, and obtain a more resilient and the least possible immunogeneic skin substitute for a future clinical application, this work studied a new keratinocyte culture system, which envisages the utilization of a fibrin substrate in association with high densities of human keratinocytes. Methods: Through light and transmission electron microscopy and immunohistochemical assays, long-term proliferative and differentiative characteristics of keratinocytes cultured onto a fibrin gel under immerse and air-liquid interface culture conditions were evaluated. Results: Despite the absence of a dermal substitute, the results demonstrated that the proposed composite was constituted of a transparent and elastic fibrin film covered by a well-attached, multistratified epithelium with morphological characteristics that resemble human epidermis, including the neoformation, albeit incomplete, of the basement membrane. Conclusions: Increased mechanical resistance due to the presence of an easy handling substrate, the delivery of nonclonfluent keratinocytes as well as the removal of animal-derived cells from the culture system suggest its potential use for future transplantation purposes.
\end{abstract}

Key words: Fibrin tissue adhesive. Keratinocytes. Immunohistochemistry. Microscopy, Electron.

\section{RESUMO}

Objetivo: Com o intuito de contornar diversas dificuldades encontradas no uso rotineiro de queratinócitos cultivados in vitro pela técnica descrita por Rheinwald e Green, e obter um substituto cutâneo mais resistente e o menos imunogênico possível para futuras aplicações clínicas, este trabalho avaliou um novo sistema de cultura de queratinócitos que prevê a utilização de um substrato de fibrina em associação com queratinócitos humanos em alta densidade. Métodos: Através de microscopia óptica e eletrônica e análise imunohistoquímica, foram avaliadas as características proliferativas e de diferenciação em longo prazo de queratinócitos cultivados em condição imersa e na interface ar-líquido. Resultados: Apesar da ausência de um substituto dérmico, foi demonstrado que o composto proposto constituiu-se de um substrato de fibrina transparente e elástico coberto por epitélio multi-estratificado, bem aderido, com características morfológicas semelhantes à epiderme humana, incluindo a neo-formação, embora incompleta, da membrana basal. Conclusões: A maior resistência mecânica com a presença de um substrato de fácil manuseio, a possível liberação de queratinócitos não-confluentes, e a remoção de células com origem animal dos sistemas de cultura sugerem que o composto proposto neste estudo apresenta grande potencial para uso clínico futuro.

Descritores: Adesivo tecidual de fibrina. Queratinócitos. Imunoistoquímica. Microscopia Eletrônica.

${ }^{1}$ Research performed at Plastic Surgery Research Laboratory, Division of Plastic Surgery, Department of Surgery, School of Medicine, University of Sao Paulo (USP), Brazil. 


\section{Introduction}

For the past three decades, skin tissue-engineering has emerged as one of the most promising alternatives that circumvents several limitations of autografting by the in vitro construction of large amounts of cultured epidermal cell sheets from a small skin sample, which may stimulate wound healing by the production of growth factors and extracellular matrix components ${ }^{1,2}$.

Although many clinical studies have demonstrated it is a recognized method for coverage of large wounds ${ }^{3-4}$, further experience showed that several disadvantages as fragility, difficult handling, time lag to obtain the needed amount, high costs, unsatisfactory graft take and prolonged instability are quite significant ${ }^{4-6}$.

In order to overcome these drawbacks and obtain a more resilient substitute, different cell delivery systems including collagen gels ${ }^{7}$, hyaluronic acid ${ }^{8}$, shark proteoglycans ${ }^{9}$, synthetic polymers ${ }^{10}$, and human allodermis ${ }^{11}$ have been previously proposed, but all of them are fraught with disadvantages ranging from lack of biocompatibility to biomechanical weakness.

Moreover, considering the possibility of late graft loss due to antigenic response originated by xenogeneic fibroblasts ${ }^{12}$, there are numerous research efforts to avoid the use of a "feeder-layer" 13 .

Based on pioneering work of Ronfard et al. ${ }^{14}$ describing the clinical use of a biocompatible substrate of fibrin glue with very promising results, the purpose of this study was to evaluate the in vitro construction of a delivery system through the direct plating, in high densities, of human keratinocytes onto a fibrin gel, observing the resulting cell morphology and function and verifying the consequences of exposing the keratinocytes to the environment using an air-liquid culture system.

\section{Methods}

This study was performed in accordance with authorization of the Ethical Committee of this institution.

\section{Fibrin gel}

The fibrin gel was prepared from a 2-ml kit of Tissucol ${ }^{\circledR}$ (Baxter-Immuno, Wien, Austria) composed of 190-mg fibrinogen and 1000-IU thrombin stock solutions. Initially, thrombin component was diluted in $1.1 \% \mathrm{NaCl}$ solution to a final concentration of $3 \mathrm{IU} / \mathrm{ml}$ thrombin and $2 \mathrm{mM} \mathrm{CaCl}$. Next, fibrinogen component was diluted in $4.32 \mathrm{ml}$ of $1.1 \% \mathrm{NaCl}$ solution. Using the double syringe mixing system provided in the kit, equal volumes of both components were mixed and gently applied onto 2 culture plates of $50 \mathrm{~cm}^{2}$. After 10 to 15 minutes at room temperature, culture plates were stored during 12 hours at $4^{\circ} \mathrm{C}$.

\section{Keratinocyte primary cultures}

Cell suspensions were obtained from skin fragments devoid of subcutaneous tissue by serial enzymatic cell separation using a $0.05 \%$ trypsin / 0.02\% EDTA solution (GIBCO-BRL Life Technologies, Rockville, MD, USA).

The cells were plated at high density ( $5 \times 10^{6}$ cells) in $25 \mathrm{~cm}^{2}$ culture flasks.

Cell cultures were fed initially with a mixture of $60 \%$ Dulbecco's Modified Eagle’s Medium (DMEM, GIBCO-BRL Life Technologies), 30\% Ham F12 (GIBCO-BRL Life Technologies) and 10\% fetal bovine serum (GIBCO-BRL, Life Technologies), supplemented with $4 \mathrm{mM}$ L-glutamine (GIBCO-BRL Life Technologies), $0.18 \mathrm{mM}$ adenine (Sigma Chemical Co., St. Louis, MO, USA), $5 \mu \mathrm{g} / \mathrm{ml}$ insulin (Sigma), $0.4 \mu \mathrm{g} / \mathrm{ml}$ hydrocortisone (Sigma), $0.1 \mathrm{nM}$ cholera toxin (Sigma), $2 \mathrm{nM}$ tri-iodothyronin (Sigma) and $100 \mathrm{IU} / \mathrm{ml}$ penicillin / $100 \mu \mathrm{g} / \mathrm{ml}$ streptomycin antibiotic solution (GIBCO-BRL Life Technologies).

The culture bottles were stored in a $5 \% \mathrm{CO}_{2}$ incubator at $37^{\circ} \mathrm{C}$. At the first medium change, the medium was further supplemented with $10 \mathrm{ng} / \mathrm{ml}$ epidermal growth factor (Sigma) and thereafter changed every 48 hours.

Cell subconfluence was usually achieved after 5 days. The cells were enzymatically released with $0.05 \%$ trypsin / $0.02 \%$ EDTA solution (GIBCO-BRL Life Technologies) and seeded onto pre-prepared fibrin gel surfaces.

\section{Immerse and air-liquid culture systems}

In order to evaluate immerse and air-liquid culture systems, 10 metal rings with diameter of $1 \mathrm{~cm}$ were applied onto the fibrin gel surface.

In each of these rings, a total of $0.16 \times 10^{6}$ cells suspended in $400 \mu \mathrm{l}$ of culture medium were plated.

Medium change was performed every third day. To avoid early fibrinolysis, $0.2 \mathrm{ml}$ of bovine aprotinin from the Tissucol ${ }^{\circledR}$ kit $(3000 \mathrm{KIU} / \mathrm{ml})$ was added to the medium at each feeding.

After culturing in the immerse situation for 7 days, 4 rings of fibrin gels with proliferating keratinocytes on the surface were raised to an air-liquid interface established with the aid of stainless steel grids. Enough culture medium was added to the well to keep the fibrin gel in contact with the medium and the cells exposed to the air. Other 4 rings were kept in the immerse condition. Cell cultures in both systems were continued for an additional period of 14 days. From the $14^{\text {th }}$ to the $21^{\text {st }}$ day of the experiments, the cell culture medium was changed daily in both immerse and air-liquid situations.

\section{Light microscopy}

Fragments of fibrin gel containing keratinocytes on the surface were removed from the immerse system at the fourth, seventh, tenth, fourteenth and twenty-first day and, from the air-liquid interface system, at the tenth, fourteenth and twenty-first day $(n=40)$.

The samples were fixed in buffered $10 \%$ formaldehyde solution, embedded in paraffin, and routinely processed for hematoxylin-eosin stain.

The number of keratinocytes was established by counting cell nuclei in ten adjoining fields under 1,000 x magnification (Labophot, Nikon, Tokyo, Japan). 


\section{Transmission electron microscopy}

Samples for electron microscopy were obtained from both culture systems at the twenty-first day after cell plating $(n=10)$.

Small segments of fibrin gel containing keratinocytes were fixed in 2\% glutaraldehyde (Ladd Research Industries, Burlington, VT, USA), dissolved in $0.15 \mathrm{M}$ phosphate buffer at $\mathrm{pH} 7.2$, followed by postfixation in $1 \%$ osmium tetroxide (Ladd Research Industries), and block staining in 1\% aqueous uranyl acetate (Ladd Research Industries). The samples were embedded in a polyester resin, thin sectioned with a LKB ultratome, double-stained by uranyl acetate and lead citrate (Ladd Research Industries), and examined with a Jeol 1010 (Tokyo, Japan) electron microscope.

\section{Immunohistochemistry}

Immunohistochemistry study for the expression of integrin beta- 4 was carried out in $3 \mu \mathrm{m}$ cuts of the embedded material in 3-aminopropyltriethoxysilane (APTS) (Sigma) after removal of paraffin with xylol and ethanol (Santa Cruz, São Paulo, Brazil) and blocking of endogenous peroxidase by $3 \% \mathrm{H}_{2} \mathrm{O}_{2}$ (Central Pharmacy, Hospital das Clínicas).

Integrin beta- 4 antigens were exposed to a $10 \mathrm{~min}$ $\left(37^{\circ} \mathrm{C}\right)$ enzymatic digestion using pepsin $0.5 \%$ and reacted against integrin beta-4 monoclonal antibodies, clone ASC-3 (Chemicon Laboratories, Billerica, MA, USA) at a 1:100 dilution.

Following treatment with incubation with the indirect dextran polymer detection system (En Vision, Dako Carpinteria, CA, USA), staining was completed by incubation with permanent red (Dako). The specimens were lightly counterstained with Mayer's hematoxylin, dehydrated and mounted with glass cover slip and xylene based mountant.

Negative controls were achieved by substituting primary specific antibodies with non-immune serum, and internal positive controls were considered according to primary manufacturer's datasheet recommendation.
All slides were analyzed morphologically under conventional light microscope (Labophot, Nikon, Tokyo, Japan) equipped with a digital camera for micrographic documentation.

\section{Statistical analysis}

Statistical and inferential analyses were performed through the Statistical Package for the Social Sciences software (SPSS for Windows 13). The assumptions of normal distribution in each group and the homogeneity of variances between groups were evaluated, respectively, with the Shapiro-Wilk and Levene's test. In all inferential analyses, a type I $(\alpha)$ error probability at 0.05 was considered. Data statistical analysis was carried out using analysis of variance (ANOVA) for repeated measures followed by Bonferroni method.

\section{Results}

\section{Fibrin gel}

In preliminary experiments, the mixture of fibrinogen and thrombin according to the manufacturer's instructions induced rapid polymerization of fibrinogen, with formation of an opaque and not homogenous fibrin matrix. Through the decrease in the concentration of thrombin from $250 \mathrm{IU} / \mathrm{ml}$ to $1.5 \mathrm{IU} / \mathrm{ml}$, reduction of $\mathrm{CaCl}_{2}$ concentration from $20 \mathrm{mM}$ to $1 \mathrm{mM}$, and the addition of $\mathrm{NaCl}$ to a final concentration of $1.1 \%$, it was possible to obtain a transparent fibrin film suitable for handling, keratinocyte cultivation and monitoring.

In order to suppress fibrinolysis led by the presence of keratinocytes, the bovine aprotinin (3000 KIU/ml) delivered in the Tissucol ${ }^{\circledR}$ kit was used and lasted for the 21 days of the experiments.

Detachment of the fibrin gel from the bottom of the culture plate was performed using a sharp periosteal elevator and surgical forceps. After detachment, the fibrin gel kept its original size, was elastic and easy to handle (Figure 1).

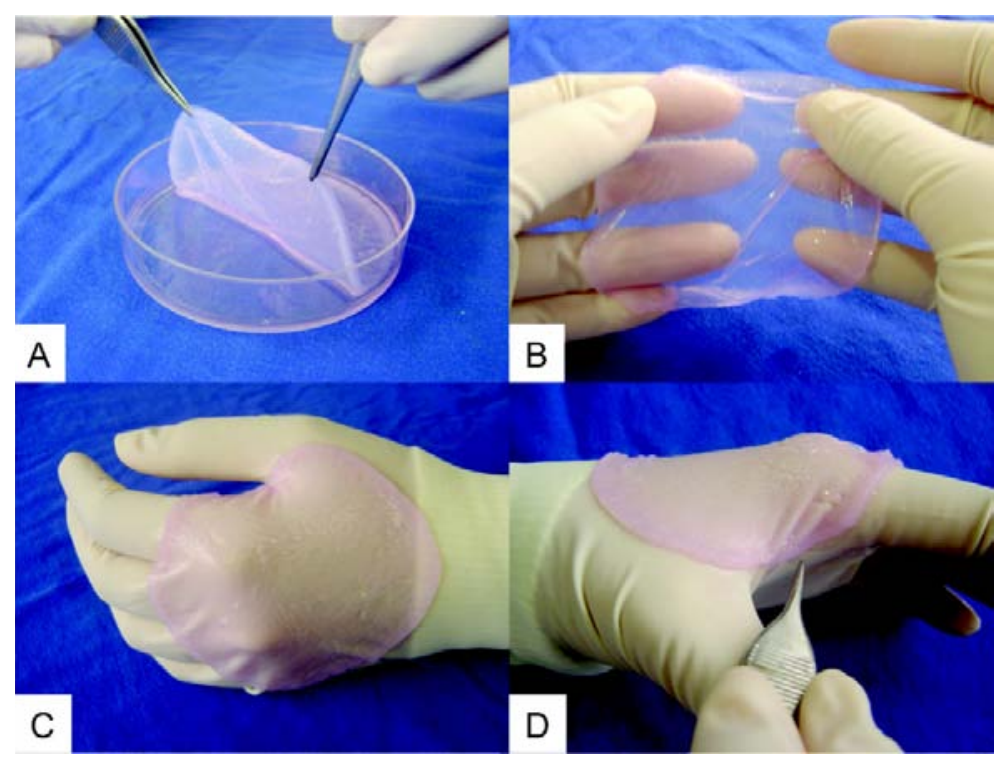

FIGURE 1 - Fibrin substrate. (A). Detachment. (B). Original size maintenance. (C). Transparency and elasticity. (D). Easy handling. 


\section{Light microscopy}

The seeded keratinocytes adhered to the fibrin gel and formed a confluent epithelia within 4 days, which progressed to stratification and differentiation. Exposure to the air was a strong stimulus for multiplication and differentiation of cells as could be well appreciated in hematoxylin-eosin stained slides at day 21 of the experiments.

The epithelium in composites exposed to the air showed significantly higher numbers of cell layers, better cellular organization, and differentiation with the formation of a true corneal layer (Figure 2).

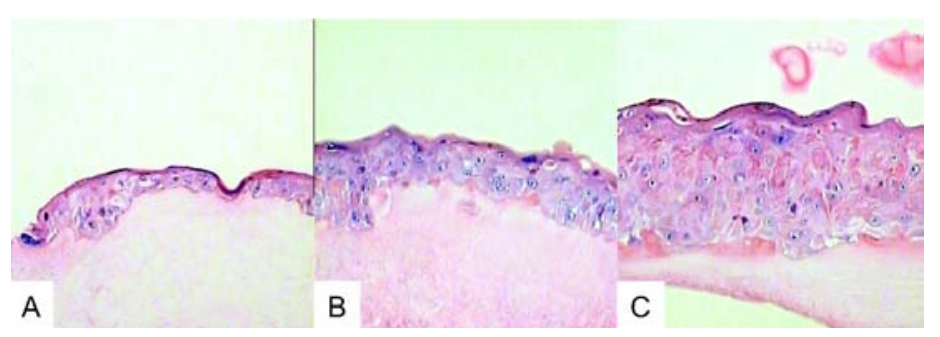

FIGURE 2 - Air-liquid interface culture situation (Light microscopy, x 400). (A). Day 10. (B). Day 14. (C). Day 21.
In the immerse culture situation, fewer cell layers could be seen, the keratinocytes were less differentiated, and a true corneal layer was absent despite the presence of some keratin lamellae (Figure 3).

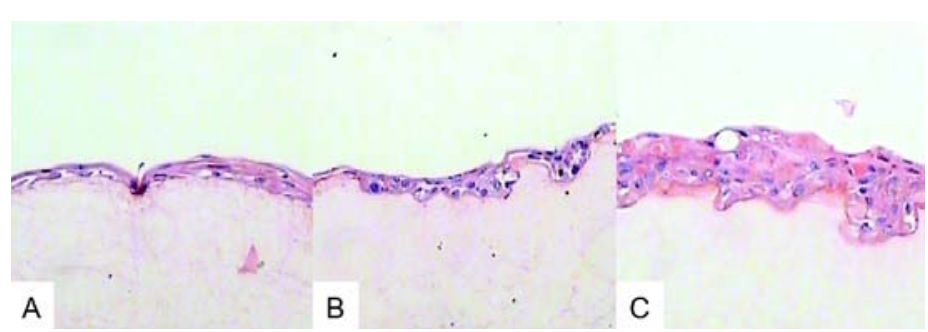

FIGURE 3 - Immerse culture situation (Light microscopy, x 400). (A). Day 10. (B). Day 14. (C). Day 21.

Mean cell counts of both immerse and air-liquid interface cultivated composites epithelia revealed increasing numbers of keratinocytes throughout the study (Figure 4), but with significant difference and consistently higher scores in the air-liquid situation at day 21 (Figure 5, Table 1).

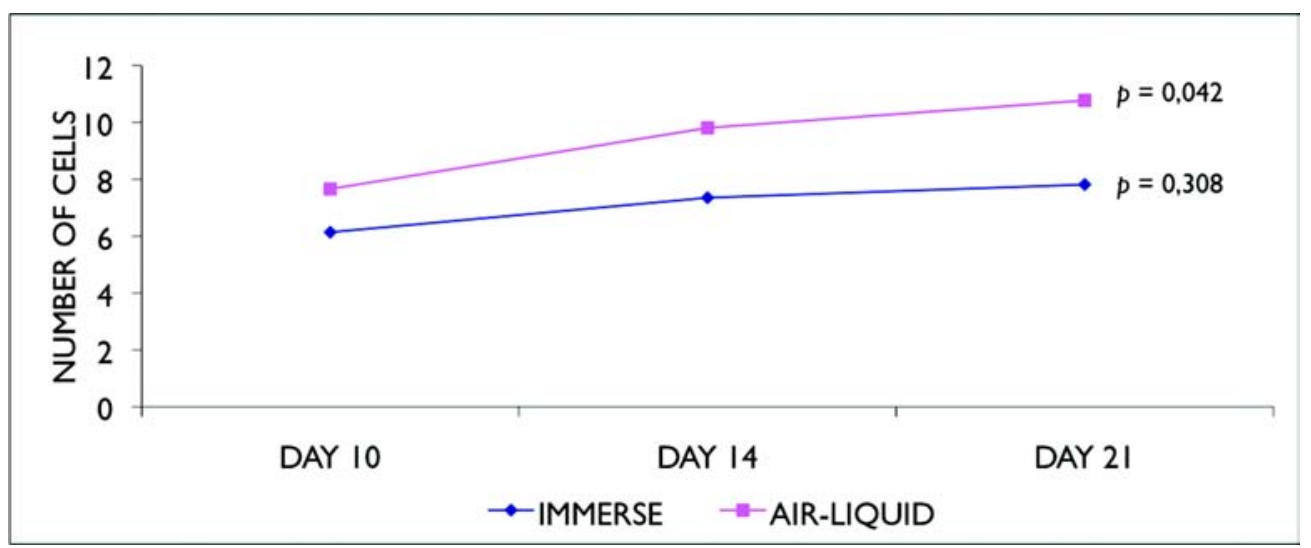

FIGURE 4 - Increasing number of keratinocytes throughout the study with no statistical interaction. Air-liquid interface culture system with significant increase $(p=0.042)$ from day 10 to day 21.

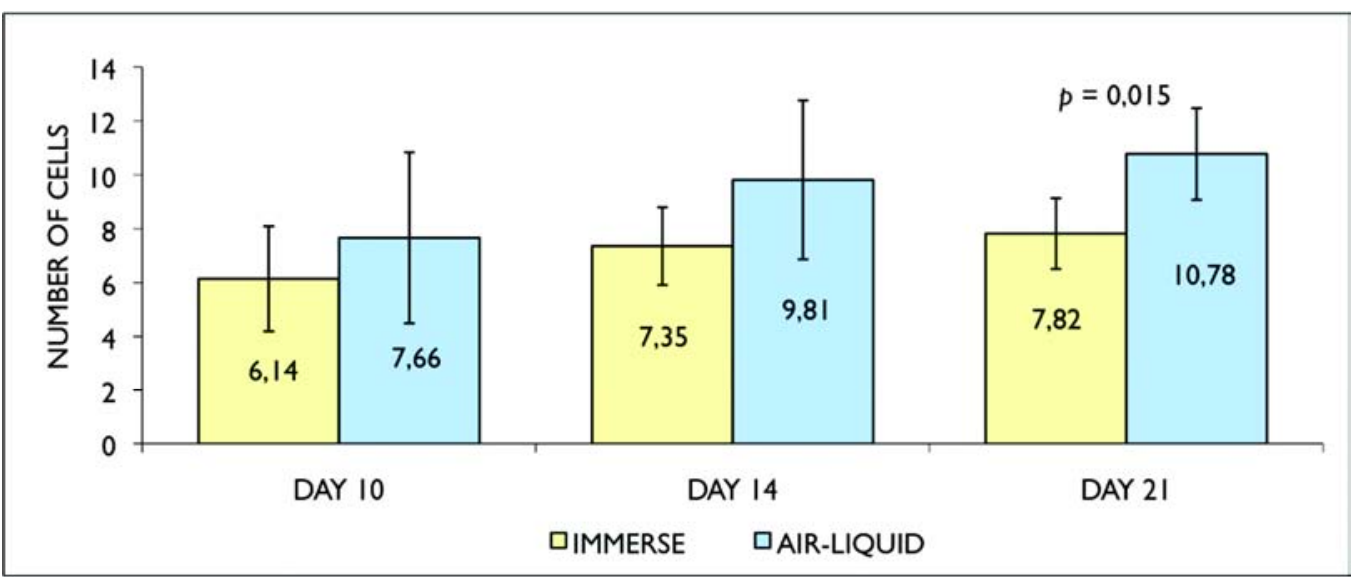

FIGURE 5 - Significant difference $(p=0.015)$ between immerse and air-liquid interface cultures at day 21, but not at day $10(p=0.388)$ and day $14(p=0.133)$. 
TABLE 1 - Mean values of counted keratinocyte nuclei (cells) viewed in 10 consecutive fields throughout the duration of the experiments in immerse and in air-liquid interface cultures

\begin{tabular}{cccccc}
\hline \multirow{2}{*}{ Day } & \multicolumn{2}{c}{ IMMERSE } & \multicolumn{2}{c}{ AIR-LIQUID } & \multirow{2}{*}{ Mean } \\
\cline { 2 - 4 } & SD & Mean & SD & \\
\hline 10 & 6.140 & 1.94873 & 7.662 & 3.17759 & 0.388 \\
14 & 7.354 & 1.44637 & 9.812 & 2.95013 & 0.133 \\
21 & 7.818 & 1.31144 & 10.776 & 1.70505 & 0.015 \\
\hline
\end{tabular}

SD: Standard deviation, $p<0.05$ = significant

In proportion to this increase of cells it was observed a progressive reduction in the thickness of the fibrin gel, especially in the air-liquid interface situation.

\section{Transmission electron microscopy}

Transmission electron microscopy confirmed the observation of good cellular organization in the epithelium cultivated on the fibrin substrate. It was possible to distinguish the stratum basale, the stratum spinosum, and the stratum granulosum; the presence of a thin stratum corneum was confirmed in the membranes of cells cultivated in the air-liquid system. Cells presented a typical distribution of organelles in each different strata. Intermediate filaments occupied a considerable volume of the cytoplasm of these cells. The network of intermediate filaments of keratin (tonofilaments) is attached to desmosomes and hemidesmossomes strucutures at cell membrane (Figure 6).

Despite the lack of a dermal component, an incomplete neoformed basement membrane could be identified in the culture systems at day 21 of the experiments, beneath hemidesmossomes-like structures. (Figure 6d).
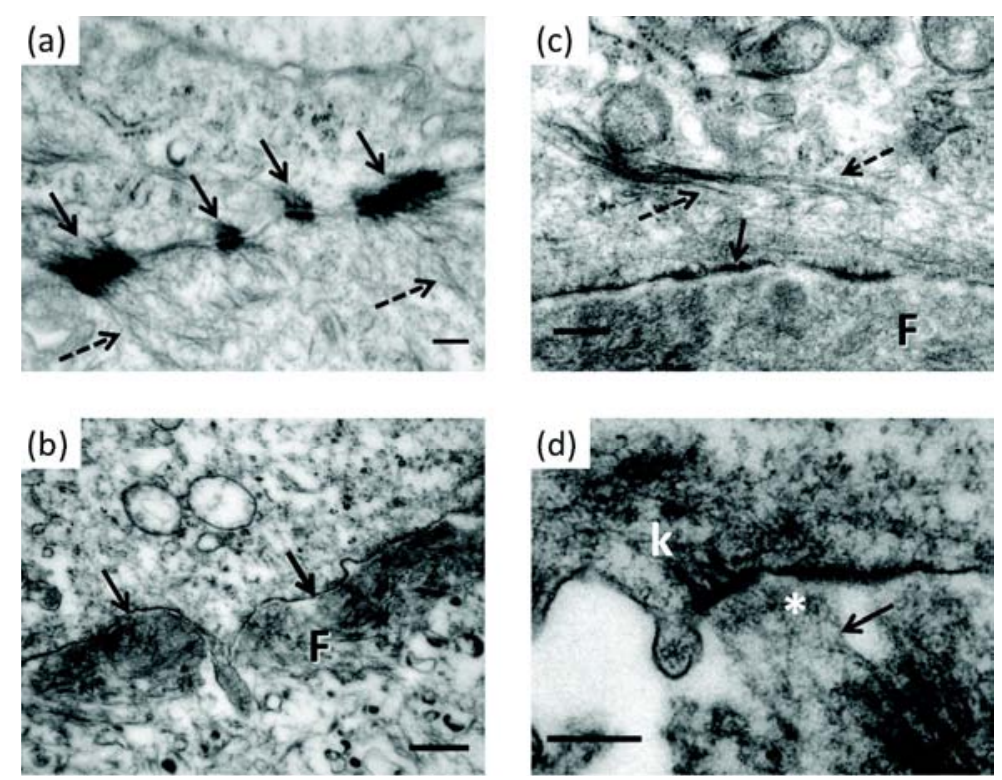

FIGURE 6 - Electron micrographs of the cultived ephitelium. (a). Portions of two adjacent cells of the stratum basale. The junctional surface of neighboring cells shows typical desmosomes (arrows) with its characteristic electron-dense cytoplasmatic plaques, laying either side of the contacting membranes of the keratinocytes. Observe that the intermediate filaments (dotted arrow) converge upon the desmosomes. (b). A region of epithelium cell-substrate association. Note the high concentration of fibrin fibers (F) underlaying the basal surface of the cell. Arrows point to the cell membrane. (c). Intermediate filaments (dotted arrows) converge upon hemidesmosomes-like structures (arrow) at the cell basal surface just above the fibrin substrate (F). (d). High power electron micrograph of the basal surface of a cell from the basal layer of the epithelium, illustrating a hemidesmosome consisting of a dense cytoplasmic plaque, the site of keratin bundle (k) attachment, a sub-basal dense plate, and anchoring filaments that project extracellularly and appear to insert into the basal lamina region (asterisk). Anchoring fibrils occur in the substrate beneath hemidesmosomes (arrow). Bars: (a, c and d) $0.2 \mu \mathrm{m}$; (b) $0,5 \mu \mathrm{m}$. 
A true corneal layer was seen in the composites cultivated in the air-liquid system, but was absent in the immerse situation where the membranes of cells in contact with the culture medium presented innumerous microvilli. Functioning melanocytes were confirmed by the presence of intracellular melanosomes.

\section{Immunohistochemistry}

Integrin beta- 4 was observed surrounding cell membrane in the various layers of keratinocytes, but a polarized pattern of expression was noted at dermoepidermal junction. At the level of the basal cells its expression was almost absent (Figure 7).

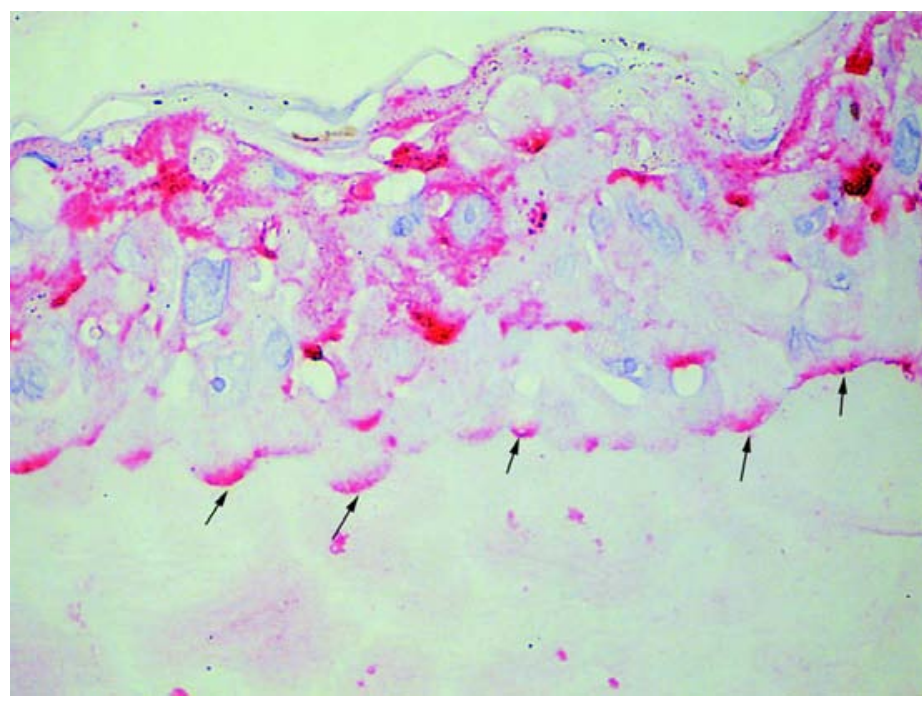

FIGURE 7 - Integrin beta- 4 expression (stained in pink) in the various layers of keratinocytes, with a polarized pattern of expression at dermoepidermal junction (arrows), and almost absent at the level of the basal cells. (Light microscopy, x 400).

\section{Discussion}

Since the breakthrough technique by Rheinwald and Green $^{1}$, it has been possible to cultivate and subcultivate keratinocytes on a "feeder-layer" of lethally irradiated mouse fibroblasts in enough quantity to cover the entire body surface of an adult within 4 to 5 weeks.

However, due to several technical difficulties, the expectations with regard to its clinical performance have not been fulfilled by their true performance yet. Detachment from the culture bottom by enzymatic treatment with Dispase may reduce antigen expression of the keratinocytes and reduce their adhesive potential $^{8,15}$; after detachment epithelia shrink to one-third their original size $\mathrm{e}^{14}$; and besides being time-consuming transfer to a backing material may damage the relatively unstable epithelium that is often prone to blister on minor trauma ${ }^{5}$.

Alternatively, culturing cells to a preconfluent state and delivering them to the wound can reduce the time needed to cultivate epithelial sheets, avoid the use of Dispase, and provide cells that have not undergone phenotypic changes associated with contact inhibition. For this, various carrier matrices including bovine or human collagen ${ }^{7}$, hyaluronic acid ${ }^{8}$, and synthetic polymers ${ }^{10}$ have been described, but so far, the effects of each of these matrices on the quality of the cultured cells have not been thoroughly evaluated ${ }^{16}$.

In contrast, fibrin is a readily available natural substrate, abundant in wound healing, and quickly degraded by the host. The use of fibrin sealant improves the percentage of skin graft take, and evidence also suggests improved hemostasis and a protective effect resulting in reduced bacterial infection ${ }^{17}$. Cell culture studies have shown that the relative percentage of holoclones, meroclones and paraclones of basal keratinocytes is maintained when keratinocytes are cultivated on fibrin, proving that fibrin does not induce clonal conversion and consequent loss of epidermal stem cells ${ }^{18}$. When they are applied on massive full-thickness burns, the take of keratinocytes is high, reproducible, and permanent ${ }^{14}$. Furthermore, it allows a significant reduction of the costs of cultured autografts and eliminates problems related to handling and transportation ${ }^{14,18}$.

However, to obtain these results, it has been emphasized that the presence of a "feeder layer" of lethally irradiated mouse fibroblasts is an absolute requirement ${ }^{14}$; and because fibrinolysis occurs rapidly as soon as epidermal cells or irradiated 3T3 cells are added $^{13}$, until now there are no long-term evaluations of the in vitro differentiation process in the epidermis reconstituted under this condition.

With the intention to obtain the least possible immunogeneic skin composite for future clinical autotransplantation with the removal of animal-derived cells, the authors successfully pursued the original in vitro construction of a delivery system through the direct plating, in high densities, of human keratinocytes onto a fibrin gel, observing the resulting cell morphology and function during 21 days.

Through combination of different concentrations of fibrinogen, thrombin and solubilization buffer, a preliminary study was performed to evaluate the formation of the fibrin substrate; but in agreement with the findings of Pellegrini et al. ${ }^{28}$ lowering of thrombin from $250 \mathrm{IU} / \mathrm{ml}$ to $1.5 \mathrm{IU} / \mathrm{ml}$, the addition of $\mathrm{NaCl}$ at a final concentration of $1.1 \%$, and the lowering of $\mathrm{CaCl}_{2}$ content from $20 \mathrm{mM}$ to $1 \mathrm{mM}$ was shown to be the best final solution for the formation of a transparent and elastic fibrin film suitable for handling and the keratinocyte culture support. However, in contrast with previously reports ${ }^{14,18}$, a twice-thick fibrin gel was necessary to enable handling. Also, to remove the fibrin-cultured autograft from the bottom of the culture plate a sharp periosteal elevator was needed in association to the two forceps. Microscopically monitoring was performed without any inconvenience.

In regards to cell growth potential, plating keratinocytes in high densities seems to have provided the needed intercellular stimuli for proliferation without reduction in the life-span capacity in the absence of a "feeder-layer". These results render possible the use of an entirely autologous approach to the development of tissue-engineered skin for transplantation purposes, eliminating risks of late graft loss to antigenic response originated by remaining xenogeneic fibroblasts ${ }^{12}$.

Fibrinolysis was noted in the presence of keratinocytes. Hence, small amounts of bovine aprotinin available in the Tissucol ${ }^{\circledR}$ kit (3000 KIU/ml) were used at each feeding, thereby significantly decreasing the fibrin degradation and allowing for the first time an in vitro experiment involving the fibrin substrate during 21 days. 
Striking differences in cell proliferation and cell maturation could be appreciated due to exposure of cells to air, but whether the formation of the corneal layer was stimulated by the need for a more efficient cell protection against dehydration or whether the fibrin gel also played the role of a filter to culture medium products reaching the cells is yet to be established.

A certain degree of morphological disorganization of the epithelium could be appreciated in both culture systems without significant cellular dysplasia. Hyperproliferative and disorganized epithelia have been described in conditions of high cell turnover, such as psoriasis or wound healing, possibly due to persistence of cell proliferation stimuli beyond wound closure ${ }^{11}$.

Keratinocyte cultures could be considered as a situation where initial cell dispersion and loss of contact is a strong promoter of the proliferation of epidermal cells with different clonogenic potentials, randomly spread on the culture plate. Different colony growth potentials result in a three-dimensional cell confluence irregularity that can be viewed as cell disorganization in histological preparations, and another contributing factor could be the absence of basal membrane components such as collagen IV and laminin, that are accredited with a signaling role for tissue organization ${ }^{19}$.

Adequate keratinocyte function and morphology was documented in transmission electron microscopy by the presence of well-formed junctional structures such as desmossomes, other intracellular organelles, and keratin granules in the more superficial layers. Additional proof of normal function of these cells was the visualization of pigment granules both in melanosomes and in the cytoplasm of adjacent keratinocytes. As previously reported, basal cells have been noted to contain fewer adhesion structures and intermediate filaments, which is consistent with the high rate of proliferation of these cells.

Hemidesmossomes-like structures, subdense plates, and electron dense deposits are testimony of the neo-organization of the dermoepidermal junction even in the absence of a dermal component, suggesting that the fibrin substrate has an important role in facilitating its formation through immediate availability of extracellular matrix proteins produced by keratinocytes.

These findings are in agreement with Ronfard et al. ${ }^{14}$ clinical comparison between fibrin-cultured autograft and control cultured epithelia that has shown that within a month of transplantation an undulated dermoepidermal junction was present underneath the grafted epithelia cultured on fibrin gel but not in the control group.

The hemidesmossome component integrin beta- 4 is the surface receptor for the basement membrane component laminin 5 , and this interaction is of crucial importance in maintaining the integrity of the integument ${ }^{20}$. In normal epidermis, integrin beta-4 is confined to the basal layers. Its expression in the basal cells strongly indicates the basement membrane formation. However, the detection of integrin beta- 4 in several layers of keratinocytes despite a polarized pattern of expression in the basal cells is innovative for cultured keratinocytes experiments and is consistent with the fetal skin development, which suggests that in the immature skin the integrin beta- 4 might play important roles in the proliferation and maturation of epithelial cells ${ }^{20}$.
The maintenance of normal proliferative and differentiative characteristics of cultured keratinocytes with the detection of a basement membrane formation even in the absence of a dermal component confirms that this new culture system does not modify the proliferative process of keratinocytes and does not induce their incorrect cell differentiation, having potential advantages as a template for cellular migration and as a delivery system for cultured cells and their growth factors.

\section{Conclusions}

The proposed fibrin substrate is an adequate support for the in vitro growth of keratinocytes. The composite resulting of the direct plating, in high densities, of human cells onto the proposed fibrin gel has ultrastructural morphological and functional characteristics that suggest its potential clinical use. There are additional benefits from increased mechanical resistance due to the presence of an easy handling substrate, which allows the delivery to the wound site of nonclonfluent cells, as well as the removal of xenogeneic murine cells ("feeder layer") from the keratinocyte culture systems.

\section{References}

1. Rheinwald JG, Green H. Serial cultivation of strains of human epidermal keratinocytes: the formation of keratinizing colonies from single cells. Cell. 1975;6(3):331-43.

2. MacNeil S. Progress and opportunities for tissue-engineered skin. Nature. 2007;445(7130):874-80.

3. Gallico GG, O'Connor NE, Compton CC, Kehinde O, Green H. Permanent coverage of large burns wounds with autologous cultured human epithelium. N Engl J Med. 1984;311(7):448-51.

4. Compton CC, Gill JM, Bradford DA, Regauer S, Gallico GG, O’Connor NE. Skin regenerated from cultured epithelial autografts on full-thickness burn wounds from 6 days to 5 years after grafting. A light, electron microscopic and immunohistochemical study. Lab Invest. 1989;60(5):600-12. 5. Desai MH, Mlakar JM, McCauley RL, Abdullah KM, Rutan RL, Waymack JP, Robson MC, Herndon DN. Lack of long-term durability of cultured keratinocyte burn-wound coverage: a case report. J Burn Care Rehabil. 1991;12(6):540-5.

6. Meuli M, Raghunath M. Burns (Part 2). Tops and flops using cultured epithelial autografts in children. Pediatr Surg Int. 1997;12(7):471-7.

7. Karasek MA, Charlton ME. Growth of postembryonic skin epithelial cells on collagen gels. J Invest Dermatol. 1971;56(3):205-10.

8. Myers SR, Grady J, Soranzo C, Sanders R, Green C, Leigh IM, Navsaria HA. A hyaluronic acid membrane delivery system for cultured keratinocytes: clinical "take” rates in the porcine kerato-dermal model. J Burn Care Rehabil. 1997;18(3):214-22.

9. Yannas IV, Lee E, Orgill DP, Skrabut EM, Murphy GF. Synthesis and characterization of a model extracellular matrix that induces partial regeneration of adult mammalian skin. Proc Natl Acad Sci USA. 1989;86(3):933-7.

10. Hansbrough JF, Morgan JL, Greenleaf GE, Bartel R. Composite grafts of human keratinocytes grown on a polyglactin mesh-cultured fibroblast dermal substitute, function as a bilayer skin replacement in full-thickness wounds on athymic mice. J Burn Care Rehabil. 1993;14(5):485-94.

11. Herson MR, Mathor MB, Altran S, Capelozzi VL, Ferreira MC. In vitro construction of a potential skin substitute through direct human keratinocyte plating onto decellularized glycerol-preserved allodermis. Artif Organs. 2001;25(11):901-6. 
12. Cairns BA, deSerres S, Brady LA, Hultman CS, Meyer AA. Xenogeneic mouse fibroblasts persist in human cultured epidermal grafts: a possible mechanism of graft loss. J Trauma. 1995;39(1):75-9.

13. Panacchia L, Dellambra E, Bondanza S, Paterna P, Maurelli R, Paionni E, Guerra L. Nonirradiated human fibroblasts and irradiated 3T3-J2 murine fibroblasts as a feeder layer for keratinocyte growth and differentiation in vitro on a fibrin substrate. Cells Tissues Organs. 2010;191(1):21-35. 14. Ronfard V, Rives JM, Neveux Y, Carsin H, Barrandon Y. Long-term regeneration of human epidermis on third degree burns transplanted with autologous cultured epithelium grown on a fibrin matrix. Transplantation. 2000;70(11):1588-98.

15. Poumay Y, Roland IH, Leclerq-Smekens M, Leloup R. Basal detachment of the epidermis using dispase: tissue spatial organization and fate of integrin alpha- 6 beta- 4 and hemidesmossomes. J Invest Dermatol. 1994;102(1):111-7.
16. Barrandon Y. The biology of epidermal stem cells. Ann Dermatol Venereol. 1998;125 Suppl 2:S5-6.

17. Currie LJ, Sharpe JR, Martin R. The use of fibrin glue in skin grafts and tissue-engineered skin replacements: a review. Plast Reconstr Surg. 2001;108(6):1713-26.

18. Pellegrini G, Ranno R, Stracuzzi G, Bondanza S, Guerra L, Zambruno G, Micali G, De Luca M. The control of epidermal stem cells (holoclones) in the treatment of massive full-thickness burns with autologous keratinocytes cultured on fibrin. Transplantation. 1999;68(6):868-79.

19. Woodley DT. Importance of the dermal-epidermal junction and recent advances. Dermatologica. 1987;174(1):1-10.

20. Wang TW, Sun JS, Huang YC, Wu HC, Chen LT, Lin FH. Skin basement membrane and extracellular matrix proteins characterization and quantification by real time RT-PCR. Biomaterials. 2006;27(29):5059-68.

Conflict of interest: none Financial source: none

\section{Correspondence:}

Dra. Daniela Y. S. Tanikawa

Av. Dr. Arnaldo, 455/1360

01246-000 São Paulo - SP Brasil

Phone: (55 11)8141-6472

Fax: (55 11)3062-0415

danielatanikawa@gmail.com

Received: March 10, 2010

Review: May 18, 2010

Accepted: June 16, 2010

\section{How to cite this article}

Tanikawa DYS, Alonso N, Herson MR, Mathor MB, Caldini EG, Lourenço SV, Ferreira MC. Ultrastructural evaluation of human keratinocyte growth and differentiation on a fibrin substrate. Acta Cir Bras. [serial on the Internet] 2010 Nov-Dec;25(6). Available from URL: http://www.scielo.br/acb

*Color figures available from www.scielo.br/acb 